\title{
Scheming the Political Landscape: A New Communist Domain
}

\author{
YIN WANG \\ School of Marxism, Lanzhou University, 222 Tianshui South Road, Lanzhou 730000, China \\ Email:wylice@163.com
}

\begin{abstract}
The paper analyses and interprets Western radical left-wing scholars' view on communism from the three dimensions of Ego, Other and the World in the modern philosophical context. The purpose of the research is to compare and reconstruct the three scientific categories of relations represented by communism, namely, the logical dialectical relations of Ego domain, Other domain and the World domain. The theoretical reconstruction and contextual analysis of Jacques Lacan and Sigmund Freud's psychoanalysis, as well as numerous researchers of their work are used. The methodological basis of this research is a philosophical reconstruction and deductive speculation, inductive speculation and insight speculation approach. It is shown that the radical left scholars reexamine the evolution of communism from three basic categories: imaginary domain, symbolic domain and real domain. Furthermore, they reconsider the construction of communism through the study of the interrelations among Ego, Other and the World. Simultaneously, they also excavate the structural contradiction of contemporary capitalism and criticise its deficiencies. The weaknesses of the argument about these relations are shown by reconstructing this upward spiral relations, which can be considered an ideal model of domain structure in 'The Neo-Communist domain'. On the basis of this claim, it is shown that these three types of domain structures may well coexist at least in ideal society, thus mankind should adhere to Marx's dialectical materialism to consider problems. The scientific significance of the research is justifying that the philosophical reconstruction does not only enrich Marxist communist ideology and is of great practical significance for Socialist countries to reshape the ideals and beliefs of Marxism, but also stick to the development of Marxism and to expand the research horizon of communism. Nevertheless, the communist thought of western radical left scholars still has the dilemma of separating theory from practice and failing to transform theoretical communism into combatant communism.
\end{abstract}

Keywords: the radical left scholar, Ego, Other, the World, the Neo-Communism

\section{INTRODUCTION}

The concept of communism is the spiritual faith of the continuous growth and development of human society, the spiritual wealth of socialism towards communism, and also the spiritual driving force of the governance of the communist Party. Terry Eagleton, in his book Why Marx Was Right, severely criticises the untrue view of the current Western anti-Marxism, which 
reflects his profound Marxist thought. Taking Eagleton's works as reference, this paper analyses and interprets Eagleton's view of communism from three dimensions, namely, Ego, Other and the World, by adopting philosophical reconstruction and deductive speculation, inductive speculation and insight speculation. Through the dialectical materialism of Marxism, this paper further demonstrates the universal connection and eternal movement of spiralling upward among the three dimensions of Ego, Other and the World. Marx believed that the motive force of movement comes from the internal contradiction of matter. The development course of contradiction is from quantitative accumulation to qualitative change, from unity of opposites to negation of negation. On this basis, Marxists believe that the history of human society is the history of class struggle, and the struggle between the two major classes in every different society leads to the change of the old form of social existence and the birth of a new form of society. Generally speaking, Marxist philosophy is a system of metaphysical knowledge. Therefore, the study of the communist social form should be based on the operational rules taking the substantive and logical knowledge of Marxism as a basis.

Vladimir Chernus (2021: 5-13) compares the notions of intentionality and 'pure Self' in phenomenological and existential traditions. In modern discourse, the existence of an integrated and indivisible 'Self' as the quintessence of consciousness is brought into question. Human actions may be deterministic or random, but not free (Harari 2019: 334). Thus, in the construction of the communist society, if humankind wants to realise the beautiful prospect of the world, it is necessary to regulate human behaviour in the established moral constraints, and realise the cultivation of personal moral sentiment in the Ego domain to the consideration of others in the Other domain, and then up to the harmonious coexistence in the World domain. In their book Commonwealth, Michael Hardt and Antonio Negri (2009) emphasised that 'the common' has become the backbone of the era of globalisation, and mankind has moved towards the development model of intersubjectivity structure featuring co-construction, sharing and symbiosis in the common world. A democracy of the multitude is imaginable and possible only because we all share and participate in the common. By 'the common' we mean, first of all, the common wealth of the material world - the air, the water, the fruits of the soil, and all nature's bounty - which in classic European political texts is often claimed to be the inheritance of humanity as a whole, to be shared together (Hardt, Negri 2009: viii).

World Marxism in the 21st century interweaves with the socialist-communist trend of thought, the radical left wing trend of thought and the new social movement in the 21 st century, forming a beautiful landscape in the contemporary world. On Socialism in the 21st Century-New Communism, 'socialism' should have three key words, namely: 'market', 'democracy' and 'ecology' as attributive. On setting with regard to communism, A. Badiou (Badiou 2010) discussed 'The Communist Hypothesis'; C. Douzina and S. Žižek (Douzina, Žižek 2010) explored 'The Idea of Communism'. In addition, G. Vattimo and S. Zabala (Vattimo, Zabala 2001) tried to reinterpret communism, and B. Bosteels (Bosteels 2011) imagines 'The Actuality of Communism'. And J. Dean (Dean 2012) looks forward to 'The Communist Horizon' and so on. In addition, J. Rancière (Rancière 1995) in La mésentente: politique et philosophie elaborated his unique aesthetic-political theory. The global financial crisis caused by the Occupy Wall Street Movement in 2008 marked the beginning of western capitalism's fall from the pedestal of history. It was followed by the arrival of the radical left ideology in the West, the return of communism as a historical trend. So far, four international seminars have been held with the theme of 'The Concept of Communism': London in 2009, Berlin in 2010, New York in 2011 and Seoul in 2013. Participants of the Conference include: Badiou, Judith Balso, Bruno Bosteels, Susan 
Buck-Morss, Costas Douzinas, Terry Eagleton, Peter Hallward, Michael Hart, Jean-Luc Nancy, Antonio Negri, Jacques Rancière, Alessandro Russo, Alberto Toscano, Gianni Vattimo, Slavoj Žižek, and a group of very well-known contemporary western left scholars. Although they have different perspectives and paths when interpreting communism, they all tend to 'return to communism' and reconstruct 'New Communism' from 'Communist Idea'. Based on this, this paper will explore the communist political landscape of the future social development on the basis of the communist thought of western radical left scholars, that is, to construct a new domain field with the Ego domain, the Other domain and the World domain.

\section{THE ORIGIN OF COMMUNISM: AWAKENING OF THE LEFT AND THEORETICAL BREAK- THROUGH}

With the outbreak of the financial subprime mortgage crisis in the capitalist world in 2008, the global economic crisis also started. It not only causes global contradictions and conflicts, but also reflects the structural system contradictions of capitalism itself at a deeper level. Of course, this contradiction is not only the economic crisis of 'foreground', but also the social crisis of 'background' (such as the destructive crisis of politics, ecology and security). In response to the destructive influence of neoliberalism, the capitalist world has witnessed an unprecedented upsurge of mass occupation movements. The economic crisis turned into a political crisis, and people began to turn away from capitalist ideology. At the same time, the people were excluded from economic activities and political participation in a procedural way, and the awareness of resistance, resistance and liberation increased. In this situation, 'the idea of Communism' has aroused the enthusiasm of the left scholars with its great potential and attraction, and the return to communism has become a new political discourse used by some leftists to advertise their radical positions. Eagleton makes a new interpretation of communism from the perspective of cultural criticism and cultural political criticism, and holds that culture and politics are related to Eagleton's conception of the human relations of communism: culture is related to the relationship between the value of man, man and man, man and society, and man and nature in the communist society; politics governs the material conditions, power relations and the social system of the above problems. In Eagleton's opinion, the origin of communism is the combination of culture and politics, and the strong response and practical attention of cultural and political criticism to his own Marxist aesthetic theory. 'Whether we can live a moral life, that is to say, a perfect life unique to mankind, ultimately depends on politics' (Eagleton 2009: 124). According to Eagleton, the desire of human society to pursue universal unity is based on actual development and future happiness. Firstly, it is suggested that the solidarity between socialist and communist societies 'requires not only material bonds, but also emotional bonds - "love" that contains the appeal for equality. Because equality is not only the possible premise to create individual autonomy, but also the guarantee to obtain complete friendship' (Jue 2019: 49). Secondly, a communist society should enable all citizens to achieve the greatest happiness. A 'society in which individual freedom and autonomy are achieved through the self-realization of others' (Eagleton 2009: 164). The communist society mentioned here highlights its 'the common' and development. As Michael Hardt and Antonio Negri said: 'This notion of the common does not position humanity separate from nature, as either its exploiter or its custodian, but focuses rather on the practices of interaction, care, and cohabitation in a common world, promoting the beneficial and limiting the detrimental forms of the common. In the era of globalization, issues of the maintenance, production, and distribution of the common in both these senses 
and in both ecological and socioeconomic frameworks become increasingly central' (Hardt, Negri 2009: viii) At the same time, it also reflects the significance of the unity and reciprocity emphasised by Eagleton.

\section{THE CONSTRUCTION OF COMMUNISM: EGO DOMAIN, OTHER DOMAIN AND THE WORLD DOMAIN}

The consideration of the structural model of communism is the dream of human society. Marx had a good plan for the communist system; Jody Dean argues, 'Rather than the individual belonging to the world, the world exists in order to belong to it' (Dean 2014: 8). Eagleton's reality anxiety about Marxists' vision and expectations are far from the institutional model of communism. Being Human, what he is really anxious about is how to realize Ego, Other and the World in a communist society, in a progressive and spiral manner. In his criticism of cultural theory, Eagleton skillfully runs the essence of his own cultural theory through his vision for the future of human society. And he placed the human nature thinking in the reciprocal and inclusive development of Ego, Other and the World domains in the communist society. The level of human horizon in a communist society directly determines the sustainable development of communist social productivity, the high degree of harmony in social relations, and the free and comprehensive development of people. Therefore, communism in the context of Eagleton's theoretical discourse corresponds to the ethics which is concerned by Eagleton. That is, the turn of ethics explained by Eagleton is closely related to the problem of human nature's fragility that the communist society is trying to solve. Eagleton's in-depth interpretation of Lacan's psychoanalytic theory is the following: 'Imaginary domain ethics - Symbol domain ethics - Real domain ethics' will help us better understand the Ego domain, Other domain and the World domain in communist society.

Firstly, it is important to put aside the traditional concept of imaginary domain ethics and regard benevolence as the basic principle and practical value of handling the relationship between people (Yin, Yunzhi 2021: 48). 'For psychoanalysis there is no such thing as an individual', Dolar writes, 'the individual only makes sense as a knot of social ties, a network of relations to others, to the always already social Other, the Other being ultimately but a shorthand for the social instance as such' (Dolar 2009). According to Eagleton, the main consideration of the mirror theory in the imaginary domain is based on the development relationship between Ego and Other as an ability to consider self-reflection. That is, 'self-reflection is in this sense a kind of inward imaginary - a matter of contemplating ourselves in the mirror of our own minds, a mental theatre in which we pass like actors before our own spectatorial gaze as though we were someone else' (Eagleton 2009: 7). Although it seems that Eagleton tries to express the ethical and moral significance of the imaginary domain, he uses ethics (i.e. practical science) to represent the mirror reflection of the communist Ego domain. As a single subject, Ego not only needs to examine the self-mind development, but also needs to reflect one's own behaviours from the perspective of Other. For Husserl, the 'transcendental Self' is a solution to the problem of intersubjectivity (Chernus 2021: 10). Therefore, the imaginary domain is also a mirror image of the Ego domain on the ethical level. Indeed, in the ethics of the imaginary domain, Eagleton explains how to appropriately handle the relationship with Other through love. As Michael Hardt and Antonio Negri said: 'Love provides another path for investigating the power and productivity of the common. Love is a means to escape the solitude of individualism but not, as contemporary ideology tells us, only to be isolated again in the private life of the couple 
or the family' (Hardt, Negri 2009: xi-xii). Only in this way can the spirit of benevolence and morality promote the spiral upward of Ego-domain through the spiritual reflection of Ego, and then rise to the moral evolution of the concern Other. As Hume believes, social morality is not a natural law derived from scientific reason, but exists in the common concern of mankind as a social practice. Therefore, as an emotional ability, Hume pays more attention to the treatment of 'is' and 'should/ought to', in which 'is' relates to the question of truth, while involves normative issues. In view of this, the morality of communism should be as follows: first and foremost, no matter how you feel, you should behave humanely and morally towards others, since its point is also that morality is a matter of what you do, not what you feel' (Eagleton 2009: 7). In the second place, it is necessary to rely on imagination to form sympathy for Other. Since 'we have no direct experience of other people's feelings, we can't know how other people fell. Only with the help of imagination, we can form the feelings of our brothers concept' (Smith 1997: 5-6). It can be seen that the sympathy of moral emotions by means of the imaginary domain can feel the Other domain in the Ego domain scene. Therefore, in the context of communism, the imaginary domain of Eagleton's deep consideration can be transformed into human self-reflection and lead to the humanization of the situation of Other.

Secondly, the ethics of symbolic domain will develop from the closed development of Ego domain to the dialogue field of benign interaction among people (Yin, Yunzhi 2021: 49). At the stage of symbolic domain, mankind must strive to obtain the domain transformation and progression from the Ego domain to the Other domain in thought and practice. 'In order to cognize a thing according to a phenomenological attitude, one must totally renounce the human, come into a state of perfect passivity, enable the thing itself, the entity itself to speak inside me. Man must cease to exist in the cognition act. Cognition takes place in the realm of ideal logical being, and not in the human realm' (Berdyaev 2004c: 39). In other words, mankind must keep up with the times due to changes in the current situation and development stage in communist society. Mankind must move from the 'little Ego' to the 'larger Ego' so as to realize the liberation and self-development of human nature in the space of Other domain. Of course, the realization of this stage of Other domain also means the self-existence and free expression of the personality of mankind as independent individuals. After all, the field space of Other domain is wider and freer. Thus, only when an independent individual (Ego) enters into the Other-domain constituted by inter-subjectivity, can he have social interaction with the real Other in the Other-domain. And then he can obtain the self-sublimation of subjectivity, instead of being constrained by a narrow expression of individuality (refers to the restriction). Of course, in the communist society, mankind are not content to have the inter-subjectivity structure of the imaginary domain covered by mirror image, but to constantly realise the moral sublimation and individual expression between themselves and others in the dialogue space of Other domain. It should be noted in advance that inter-subjectivity and individual free expression in the Other domain are by no means once and for all. It must comply with the rules and regulations of law emphasised by Eagleton.

Thirdly, the pure desire in the real domain cannot be fully expressed and realised. Therefore, the realistic domain ruled by pure desire is totally opposite to the real world. And they move towards two different development situations. As the realistic domain of communist society, it is nothing more than the realization of the real world domain of human society. It is not derived from the pure desire of instinct in human nature, because this pure desire cannot be satisfied and it is even more superficial (Yin, Yunzhi 2021: 49). Once the uncontrollable desire dam in human nature is opened, it will cause disastrous consequences to human society. As 
Jody Dean said: 'When bourgeois ideology fails, individuation fails and the fact of collectivity impresses itself. A problem faced by one becomes a condition shared by many. Correspondingly, the subject is a gap in the structure because the people are the subject of politics' (Dean 2014: 10). The implication is that once the individuality in the real domain is opened, it will cause the loss or even failure of collectivism in the World domain. After all, people are the subject of the world. Only by regulating individualism in the World domain of collectivism can human beings achieve the collective development in the world. In view of this, in the communist society, the real realisation and expression of the World domain should comply with the objective rule of the development of things, regulate the Ego domain of the imaginary domain in human nature within an established moral framework, and do not allow empathy to spread the moral boundary of Other domain in case that the World domain would become rampant and irreparable. As a subject, mankind is unable to sublimate the level of Other in the scene of Ego domain, so it moves towards the transcendent response to the symbolic order, and thus realises the transcendent expression of the communist society in the scene of real world domain as a necessary existence entity. In such a world, subjects enter only into object relations with each other and, directing their consciousness to the object, objectify themselves, that is, turn into objects (Chernus 2021: 7). Facing the change and development of the subject and object, the subject realises the emancipation state between its own desire and the existing social system. However, it should be noted that the development of mankind self-desire should be based on the framework of the existing social system (here refers to the communist society). The real domain ruled by pure desire must not be released and liberated in a comprehensive manner without scruple. Otherwise, the communist society would go into substantial retrogression. After all, human nature is an inherent absolute spiritual force that cannot be absolutely controlled. In the face of the high degree of freedom of communism, mankind may not be able to control themselves, leading to a domino effect or opening a magical effect of Pandora's Box.

From the above analysis, the World domain in the context of the real domain should transcend the transcendentalism of pure desire, connecting integrally the subjectivity desire of self-existence from mankind with the real situation in the World domain and striving to construct a real development scene in which the triple relations of Ego, Other and the World are interconnected and complement each other. In Husserl's idealistic interpretation, the phenomenal field is interpreted as the field of pure transcendental subjectivity - the field of 'world as meaning, which is effortlessly constituted by an active meaning-generating operation (Sinngebung), which is the very definition of 'pure consciousness'. This transcendental field of consciousness is neither 'mine', nor 'yours', nor 'ours'(Chernus 2021: 10). Thus, an individual should connect the subject with Other, and effectively building an equal and mutually beneficial relationship between each other, so that Ego and Other can be liberated and developed freely in the World domain.

\section{THE PATH OF 'COMMUNIST DOMAIN': 'NEO-COMMUNIST PARTY - PLATFORM ME- TA-STRUCTURE - NEO-PEOPLE'}

The prospect and practice of communism by the western radical left scholars makes the return of communism possible. Returning to communism not only requires the victory of theoretical communism, but more importantly, on the basis of abundant theoretical resources, but also it can promote the effective practice of combatant communism in accordance with laws and regulations. 


\section{The Unconcealedness of the Framework of the Traditional 'The Old Communist Domain'} At present, the western radical left scholars represented by Hart, Negri, Eagleton, Costas Douzinas and Dean have made great progress in constructing theoretical communism, realising the logical framework of the communist model in promoting the organic tenon and high sublimation of Ego domain, Other domain and the World domain. In the era of globalization, the traditional theoretical structure of 'The Old Communist domain' has been broken by the diversified, fluid and holistic model of 'The Neo-Communist domain', and replaced by the rise and expansion of the global communist domain. To some extent, the Ego domain and the Other domain, which are both in the World domain, coexist harmoniously in the construction of the community with a shared future for mankind, adopting a developing mode which combines both features of a national community and the coexistence of a diversified World domain that is a 'cross-domain public sphere'. For the western radical left scholars, 'The Neo-Communist domain' is a non-bourgeois competitive and antagonistic public domain which breaks through bourgeois public domain and finally moves to the world communist domain in a wide sense, as shown in Fig. 1:

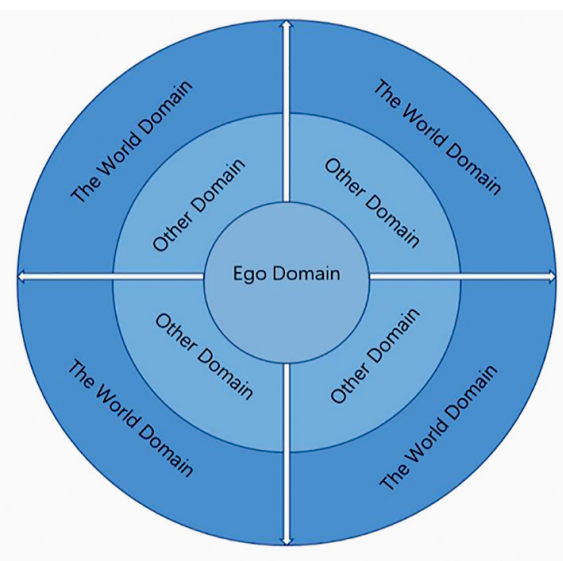

Indeed, in the open public domain ('The Neo-Communist domain'), due to each other's interests and hobbies, human beings are moving toward a community of shared future for common development, and human beings are also adhering to the national community of their nation states due to the differentiated needs and values of the times. However, this can never replace the historical development law of human liberation and development, namely, moving toward a free and all-round development of the communist society.

\section{The Construction of the Theoretical Model of Communist Development}

With the development of society, the construction of 'Neo-Communism' in the era of globalization has become the need of the times. Communism ought to construct a theoretical development model based on the Ego domain, the Other domain and the World domain. In the development field and extension level of 'The Neo-Communist domain', communism should constantly challenge the framework structure of the traditional 'The Old Communist domain', unmask human beings from the bound public domain, move towards the World domain expanded by 'The Neo-Communist domain', and further expand the human public domain. Thus it lays a solid theoretical foundation for the construction of the theoretical model of communist development. Based on Marx's communist thought, communicative network media platform as the 'meta-structure', digital loop as the 'driving force', with the help of the situation of 'communicative capitalism' and the power of 'Neo-People', we are attempting to construct a setting of 'Neo-Communism', considered 'Neo-People' as the main structure, 'the Neo-Communist Party' as the leadership, with the comradeship of the new era, as shown in Fig. 2 below: 


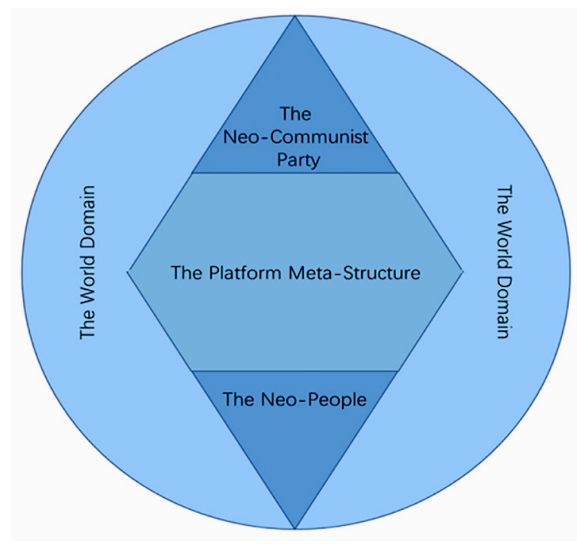

Although the ternary structure theory system of 'Neo-Communist Party - Platform Meta-Structure - Neo-People' is exceedingly creative used to consider that the development mode of Neo-Communism, which is in line with the operative mode of network communism era. However, whether the theoretical communism can be effectively transformed into combatant communism or not, it is necessary to continue to adhere to the logical upward movement of Ego domain, Other domain and the World domain, and take the Neo-People movement under the leadership of the Neo-Communist Party. As Dean pointed out, "The Communist Party" is a myth, a signifier, an ideal type, the big Other of the Symbolic. It's a form or formalization of political belonging separate from any existing empirical party' (Dean 2020: 9-10).

\section{CONCLUSIONS}

In a word, the consideration of the western radical left scholars on 'The Neo-Communist domain' in the era of globalization reflects their academic style as critical theorists advocating Marxist's research paradigm. The criticism of 'The Old Communist' public domain theory by the left scholars represented by Slavoj Žižek, Terry Eagleton, Jody Dean, Bruno Bosteels and Costas Douzinas has found an idealised way for the construction and development of 'The Neo-Communist domain' theory. 'The Neo-Communist domain' is also transforming from the traditional empirical social field to the theoretical political space, but this does not mean that 'The Neo-Communist domain' theory has moved towards the revolutionary road of complete practice. After all, in the field of 'The Neo-communism', namely the World domain where there are many difficult dilemmas, such as whether there are conflicts and antagonism between the Ego domain and the Other domain, whether the Neo-People's subjectivity movement under the leadership of the Neo-Communist Party is moving towards comradeship, whether the Platform Commons is developing in a public way, and whether the people's subjectivity force is moving towards collective development. Of course, there are still great distinctions in the development of people's subjectivity, and the logical connotation of publicity and the value implication of commons need to be further explored. In view of this, we should maintain a critical attitude towards the construction of the theory of 'The Neo-Communist domain', and analyse, judge and think by means of Marxist's communist thought, thus realise the communism theory of 'grand narrative' takes root, seek the theoretical guide for human happiness and scheme the political landscape for human liberation.

Received 2 April 2021

Accepted 13 December 2021

\section{References}

1. Badiou, A. 2010. The Communist Hypothesis. London, New York: Verso.

2. Berdyaev, N. A. 2004c. Destiny of Man. Experience of Paradoxical Ethics. Moscow: AST (in Russian).

3. Bosteels, B. 2011. The Actuality of Communism. London, New York: Verso.

4. Chernus, V. 2021. 'Non-classical Intentionality: An Existential View', Filosofija. Sociologija 32(1): 5-13. 
5. Dean, J. 2012. The Communist Horizon. London: Verso.

6. Dean, J. 2016. 'Enclosing the Subject', Political Theory: 44(3): 363-393.

7. Dolar, M. 2009. 'Freud and the Political', Theory \& Event 12(3).

8. Douzina, C.; Žižek, S. 2010. The Idea of Communism. London, New York: Verso.

9. Eagleton, T. 2009. After Theory. Trans. Z. Shang. Beijing: Commercial Press.

10. Eagleton, T. 2011. Why Marx Was Right. 1st ed. New Haven, London: Yale University Press.

11. Harari, Y. N. 2019. Homo Deus: A Brief History of the Future. Moscow: Sinbad (in Russian).

12. Hardt, M.; Negri, A. 2009. Commonwealth. Cambridge, Mass.: The Belknap Press of Harvard University Press.

13. Jue, F. 2019. 'A Political Column of Capitalist Ethics Based on the "Other" Question - On Eagleton's "Ethical Turn”, Social Science (3).

14. Marx, K; Engels, F. 2009. Collected Works of Marx and Engels. Bejing: People's Publishing House.

15. Rancière, J. 1995. La mésentente: politique et philosophie. Paris: Galilée.

16. Smith, A. 1997. Theory of Moral Sentiments. Trans. J. Ziqiang, Q. Beiyu, Z. Zhongdi, S. Kaizhang. Beijing: Commercial Press (in Chinese).

17. Vattimo, G.; Zabala, S. 2001. Hermeneutic Communism: From Heidegger to Marx. New York: Columbia University Press.

18. Yin, W.; Yunzhi, M. 2021. 'Self, Other, the World - Study on the Terry Eagleton's Communism Ideology', Inner Mongolia Social Science (2).

YIN WANG

\title{
Formuojant politinị kraštovaizdị: nauja komunistinė erdvè
}

\begin{abstract}
Santrauka
Straipsnyje analizuojamas ir aiškinamas vakariečių tyrinètojų požiūris i komunizmą iš trijų - Ego, Kito ir Pasaulio - perspektyvų šiuolaikiniame filosofiniame kontekste. Straipsnio tikslas yra rekonstruoti ir palyginti tris mokslines santykių kategorijas, reprezentuojamas komunizmo: loginius dialektinius ryšius Ego, Kito ir Pasaulio erdvėse. Remiamasi Jacques'o Lacano ir Sigmundo Freudo psichoanalizės teorinėmis rekonstrukcijomis ir kontekstinemis analizėmis. Parodoma, kad radikaliosios kairès tyrinètojai permąsto komunizmo evoliuciją per tris pagrindines kategorijas: ịsivaizduojamybės, simbolinès ir tikrovès erdves. Taip pat jie parodo struktūrines šiuolaikinio kapitalizmo prieštaras ir kritikuoja jo trūkumus. Rekonstruojamas kylančios spiralès santykis, kuris gali būti laikomas „neokomunistinès erdvès“ struktūros modeliu. Atskleidžiama, kad trys minètos erdvių struktūros gali puikiai koegzistuoti bent jau idealioje visuomenèje, tad žmonija, spręsdama problemas, turètų laikytis Karlo Marxo dialektinio materializmo. Filosofinè rekonstrukcija papildo marksistinę komunistinę ideologiją ir turi praktinès reikšmès socialistinėms šalims, taip pat išplečia marksistinio komunizmo tyrimų horizontą. Vis dèlto Vakarų tyrinètojų komunistinè mintis išlieka teorijos ir praktikos perskyros dilemoje ir nesugeba performuoti teorinio komunizmo ị kovingaji.
\end{abstract}

Raktažodžiai: radikaliosios kairès tyrinètojas, Ego, Kitas, Pasaulis, neokomunizmas 